\title{
Groundwater quality and sustainability in granitised-fractured aquifers, Pallisa district, eastern Uganda
}

\author{
J. Nyende \\ Water Engineering Section, Department of Civil and Building \\ Engineering, Kyambogo University, Kampala, Uganda
}

\begin{abstract}
The sustainability of the granitised aquifer system of the Kyoga catchment has been threatened by the ever increasing population that will lead to over exploitation of the groundwater resource. Uganda's freshwater is considered a key strategic resource which is vital for sustaining life, promoting development and maintaining the environment. The increasing pressure from domestic, industrialization and urbanization, agricultural as food security and hydropower uses due to population and industrial growth combined with environmental degradation and extreme poverty are relatively putting pressure on the quantity and quality of water resources. Groundwater quality in Uganda is originally influenced by the rainwater in some areas and the Nile, which recharge the aquifers from where boreholes are drilled and dug up wells. Boreholes data show the highest degree of mineralisation with relative enrichment of nearly all tested elements and is due to the ability of aggressive groundwater to decompose the relatively fresh minerals in the bedrock fractures. Plots of boreholes situated in these aquifers of Pallisa represent a regime where there is calcium enrichment, which is typical of lime dosing to neutralize acid waters. The plot of water contains approximately $70 \% \mathrm{Ca}, 70 \% \mathrm{Mg}, 80 \%$ TAlk, $10 \% \mathrm{Cl}$ and $10 \% \mathrm{SO}_{4}$. This is typical of calcium/magnesium bicarbonate waters. Higher concentrations of aluminium are observed in the regolith while low levels in the bedrock. The significantly lower level of aluminium in the bedrock aquifer provide further support for the notion of relatively limited hydraulic interaction between the two units. An urgent need for a holistic approach to water resources management is required to protect the available water resources and to satisfy the sometimesconflicting demands while ensuring sustainable water resources development. Collection and analysis of water resources related data and information is one of the priority areas for the water resources management sub-sector.

Keywords: groundwater quality, sustainability, rock interaction, fracturedbedrock, wastewater, basement complex, Eastern Uganda, degree of mineralisation, sodium absorption ratio, regolith, granitised.
\end{abstract}




\section{Introduction}

The populations of most development countries are growing at a high rate. It is likely that the total use of groundwater will increase even when conservation measures are taken. Groundwater therefore, has become increasingly popular in Pallisa district. Water being a finite resource, and with the increasing population in the district coupled with deficiency of safe water points, there is a need to identify more safe sources of supply of this limited resource. Therefore, due to high demand for the invaluable resource, work on providing adequate good quality water is essential. However, despite the widespread increase in development of groundwater resources, there has been a population increase that has caused an increase in several activities - agricultural irrigation, livestock and domestic water supply within Pallisa district.

The challenge facing planners, implementers and policy makers in Uganda now, is to ensure sustainable groundwater exploitation, utilisation, prevention of exhaustive abstraction and groundwater-related pollution. It should be realised that the priority in groundwater is directly emphasised on the sustainability of the resources with respect to both quantity and quality. Knowledge of the spatial and temporal characteristics of groundwater systems and their interactions with the environment provides the basis for such sustainable development and environmentally sound planning and management of groundwater resources.

The study on groundwater chemistry in the Naivasha area explained that the quality of groundwater has deteriorated due to high level of nitrate from agricultural activities as well as high-level fluoride (Morgan [1]). The Rural Water and Sanitation Project (RUWASA) and Small Towns Water and Sanitation Project under Directorate of Water Development (DWD) set up water supply projects that were intended to bring safe water to millions of Ugandans in the rural communities by use of groundwater. The focus however, was on delivery (construction of water systems). This has been at the expense of equity and sustainability.

\section{Site description}

Pallisa district is situated in the eastern part of Uganda and it is neighboured by Iganga district to the south-west, Kamuli district to the west, Tororo district to the south, Soroti district to the northwest, Kumi district to the north and Mbale district to the east. It occupies an area of $1956 \mathrm{~km}^{2}$ with a population of 357656 according to the 1991 census. The density of the area is 229 people per square kilometer. It is located between latitude $33^{\circ} 25^{\prime \prime}$ East and $34^{\circ} 09^{\prime \prime}$ East and Longitude $0^{\circ} 50^{\prime \prime}$ North and $1^{\circ} 25^{\prime \prime}$ North. The District Headquarters are located at Pallisa, with major towns of Budaka, Kamuge, Kibuku and Butebo. A location map of the area under investigation is as in Figure 1 below.

\subsection{Geology}

The geology of Pallisa is generalised and can be described as undifferentiated gneisses including elements of partly granitised and metamorphosed formations. 
It consists of however, a gneissic complex formation. Gneiss and granitic formations of the Pre-Cambrian predominates which are usually referred to as gneiss complex. The northern part is largely underlain by older, wholly granitised or medium to high-grade metamorphic formations. However, thin pleistocene deposits are the most widespread representatives of the post-Cambrian deposition. Volcanic activity occurred during the Lower Miocene in eastern Uganda (Elgon, Moroto, Kadam and Napak), which in some areas are underlain by sediments possibly of cretaceous age, and during the late pleistocene over a small area.

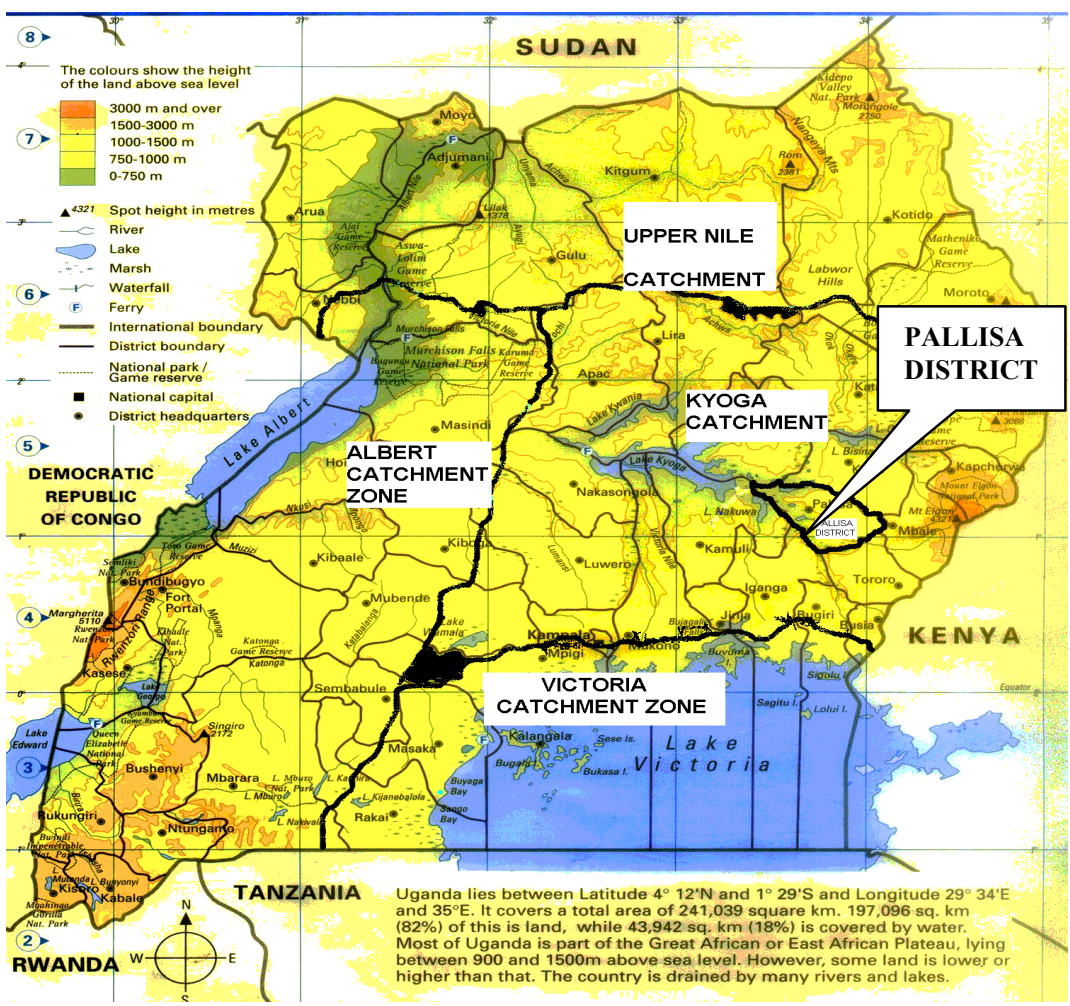

Figure 1: Location of the study area within Uganda; Source: NCDC, Uganda [2].

\section{Hydrogeology}

In much of this study area, groundwater is widely available and fairly free from sediment and biological impurities that frequently plague surface waters. Considering the rural population of Pallisa district, which relies exclusively on groundwater as the only potable water source, many thousands of boreholes which have been put into production were constructed in 1930s. Until very 
recently, the preferred method of well construction has been to drill relatively deep wells that fully penetrate the overlying regolith, or "weathered zone" and rely on fractures in the competent underlying rock to provide an adequate well yield.

Throughout Pallisa district, crystalline basement rocks are extensively concealed by the regolith, which is the result of intense chemical weathering. The extent of the chemical weathering, and hence development of the regolith, depends on the nature of the basement rock including its age, structure and lithology, as well as climate and relief. Key [3], found out that chemical weathering is enhanced by joints, fractures and coarse grains in the bedrock that expose a greater surface area to groundwater, which is the principal weathering agent. According to Briggs et al [4], the high rainfall and temperature of tropical climates serve to increase the rate at which chemical weathering processes occur as a result of hydrolysis, oxidation and dissolution. Taylor et al [5] described the deeply weathered crystalline rocks that form important aquifers for public water supply throughout low-latitude regions of Africa, South America, and Asia, and that these aquifers have considerable heterogeneity and produce low well yields.

There are two units that form an integrated aquifer system in which transmissivity lies $\left(5-20 \mathrm{~m}^{2} / \mathrm{d}\right)$ and porous weathered mantle that provides storage to underlying bedrock fractures $\left(T=1 \mathrm{~m}^{2} / \mathrm{d}\right)$. The thickness and extent of the more productive weathered-mantle aquifer are functions of contemporary geomorphic processes. Generally, a lateritic, sub-humus soil horizon rests over a clay unit formed from secondary weathering of basement rock fragments. The water table tends to lie at the base of the clay where fragments of the parent bedrock pre-dominate the bedrock surface. As an indicator in the evaluation process, the water resource is monitored, managed and exploited in a sustainable and equitable manner (Nyende and Hodgson [6]).

\subsection{Groundwater chemistry}

Hydro-chemical evaluation of groundwater from the regolith and basement aquifers were undertaken in Pallisa district and the groundwater samples analysed for minor and major elements. This was to enable the quality of groundwater presently being pumped from the fractured bedrock aquifer to be compared to the quality of water, as per the WHO [7] guidelines that could be expected from the development of the regolith aquifer. See figure 1 below.

In terms of organic chemistry, the conductivity values (and thus degree of mineralisation) are significantly lower for springs than for dug wells and lower in boreholes. This is explained by the fact that spring water trajectories have been intensively leached through many years of flow whereby the water in these aquifers shows relatively manor enrichment in organic substances. Spring water show the lowest $\mathrm{PH}$ values, which demonstrates that water, in spite of the low $\mathrm{PH}$, has caused limited decomposition of aquifer minerals. Boreholes on the other hand, show the highest degree of mineralisation with relative enrichment of nearly all tested elements. This is due to the ability of aggressive groundwater to decompose the relatively fresh minerals in the bedrock fractures. 
Table 1: Average values for water quality parameters from dug wells, protected springs and boreholes in Pallisa district.

\begin{tabular}{|c|c|c|c|c|}
\hline PARAMETER & $\begin{array}{c}\text { AV. } \\
\text { DUG } \\
\text { WELLS } \\
\text { (Nos. }=24)\end{array}$ & $\begin{array}{c}\text { AV. } \\
\text { PROTECTED } \\
\text { SPRINGS } \\
\text { (Nos. }=28)\end{array}$ & $\begin{array}{c}\text { AV. } \\
\text { BOREHOLES } \\
(\text { Nos. }=38)\end{array}$ & $\begin{array}{c}\text { WHO } 1984 \\
\text { GUIDELINES }\end{array}$ \\
\hline $\mathrm{PH}$ & 6.8 & 5.8 & 6.7 & $6.5-8.5$ \\
\hline Conductivity, $\mu \mathrm{S} / \mathrm{cm}$ & 390 & 113 & 737 & - \\
\hline Total iron, $\mathrm{mg} / \mathrm{l} \mathrm{Fe} e^{2+}+\mathrm{Fe}^{3+}$ & 0.5 & 0.3 & 0.8 & 0.3 \\
\hline Manganese, $\mathrm{mg} / \mathrm{l} \mathrm{Mn}^{2+}$ & 0.10 & 0.05 & 0.07 & 0.1 \\
\hline Alkalinity, $\mathrm{mg} / \mathrm{l} \mathrm{CaCo}_{3}$ & 119.5 & 38.8 & 186.1 & - \\
\hline $\mathrm{T}$-Hardness, $\mathrm{mg} / \mathrm{l} \mathrm{CaCo}_{3}$ & 124.6 & 48.4 & 229.8 & 500 \\
\hline Calcium, $\mathrm{mg} / \mathrm{l} \mathrm{Ca}{ }^{2+}$ & 41.0 & 20.7 & 94.1 & - \\
\hline Magnesiun, $\mathrm{mg} / \mathrm{l} \mathrm{Mg}^{2+}$ & 9.1 & 5.2 & 22.1 & - \\
\hline Bicarbonate, $\mathrm{mg} / 1 \mathrm{HCO}_{3}$ & 140.5 & 51.1 & 216.3 & - \\
\hline Carbon dioxide, $\mathrm{mg} / 1 \mathrm{CO}_{3}$ & 97.5 & 126.5 & 165.6 & - \\
\hline Sodium, $\mathrm{mg} / \mathrm{l} \mathrm{Na}^{+}$ & 25.3 & 6.4 & 60.6 & 200 \\
\hline Potassium, mg/l K ${ }^{+}$ & 5.6 & 1.6 & 5.1 & - \\
\hline Chloride, $\mathrm{mg} / \mathrm{l} \mathrm{Cl}-$ & 22.1 & 9.3 & 73.4 & 250 \\
\hline Sulphate, $\mathrm{mg} / \mathrm{l} \mathrm{SO}_{4}{ }^{2-}$ & 27.8 & 12.8 & 57.5 & 400 \\
\hline Phosphate, $\mathrm{mg} / 1 \mathrm{PO}_{4}^{2-}$ & 1.3 & 0.4 & 0.8 & - \\
\hline Nitrate, $\mathrm{mg} / 1 \mathrm{NO}_{3}^{-}$ & 2.2 & 2.6 & 3.7 & 10 \\
\hline Fluoride, $\mathrm{mg} / \mathrm{l} \mathrm{F}^{-}$ & 0.7 & 0.14 & 0.8 & 1.5 \\
\hline TAlk, mg/l & 186 & 173 & 211 & - \\
\hline$\%$ Water points with E.Coli count $>0$ & 34 & 13 & 5 & 0 \\
\hline Aluminum, mg/l & 0.46 & 0.35 & 0.5 & 0.2 \\
\hline Turbidity, NTU & 0.8 & 0.15 & 0.39 & 5 \\
\hline TDS, mg/l & 460 & 350 & 375 & 1000 \\
\hline
\end{tabular}

The figures in bold, table 1 indicate the values not in accordance with WHO guidelines.

\subsection{Groundwater quality}

The groundwater quality in the catchment was assessed by electrical conductivity (EC) and sodium absorption ratio (SAR), see figures 3 and 4 and table 2 below.

Table 2: $\quad$ Water quality in Pallisa district.

\begin{tabular}{|c|c|c|}
\hline $\begin{array}{l}\text { Salinity Hazard } \\
\mathrm{EC}(\mu \mathrm{S} / \mathrm{cm})\end{array}$ & $\begin{array}{r}\text { Sodium } \\
\mathrm{S} A\end{array}$ & $\begin{array}{l}\text { Iazard } \\
\mathrm{R}\end{array}$ \\
\hline $\mathrm{C} 1<25$ & $\mathrm{~S} 1<10$ & $\mathrm{~L}$ \\
\hline $\mathrm{C} 225-75 \quad \mathrm{M}$ & $\mathrm{S} 1<10$ & $\mathrm{~L}$ \\
\hline C3 $75-225 \mathrm{H}$ & $\mathrm{S} 1<10$ & $\mathrm{~L}$ \\
\hline $\mathrm{C} 4>255 \quad \mathrm{VH}$ & $\mathrm{S} 1<10$ & $\mathrm{~L}$ \\
\hline
\end{tabular}


Figures 2, 3, 4, 6, 7 and 8 show the chemistry composition of some of the drilled boreholes in Pallisa district. The water quality in almost all the boreholes in Pallisa district is relatively safe for drinking purposes.

Figure 4 shows the salinisation of the boreholes shown is generally very low, but the sampling points on the right of the diagram has a very high electrical conductivity as one moves away from River Mpologoma. (See the position of borehole CD2641, Fig.5.) The decrease in salinity is due to dilution along or near the Mpologoma River.

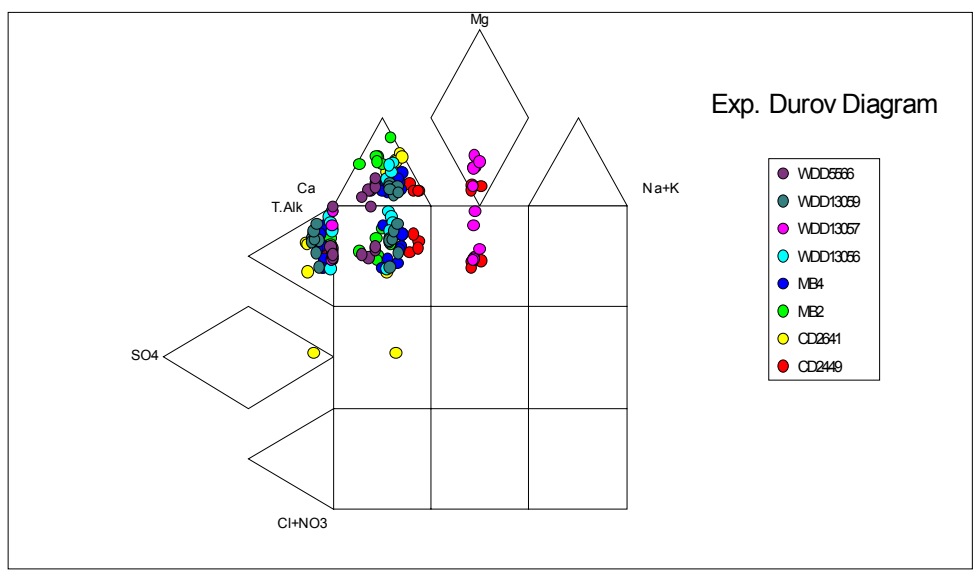

Figure 2: Concentrations of different ions in the expanded durov of all the boreholes drilled in Pallisa.

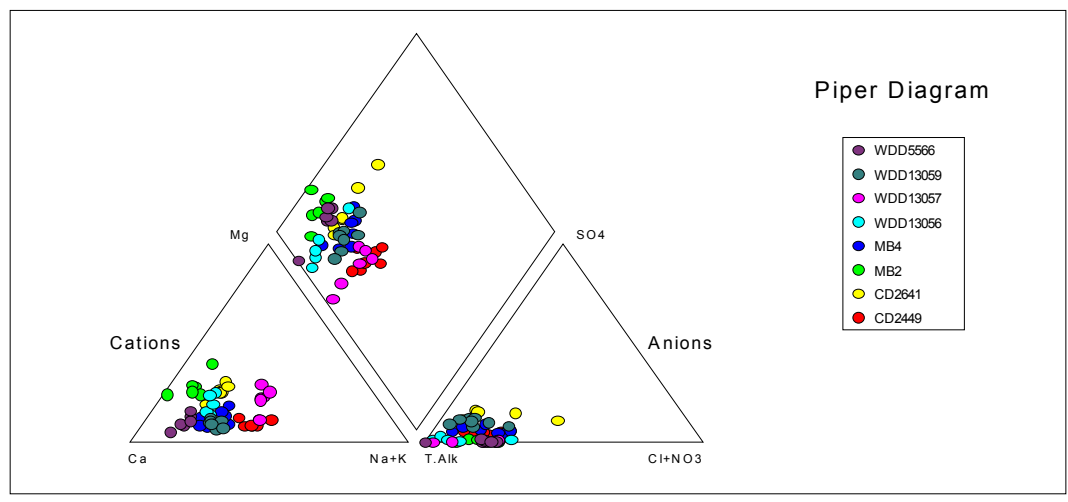

Figure 3: Piper diagram of groundwater from the boreholes in Pallisa, lying in both the regolith and the basement complex (bedrock). 


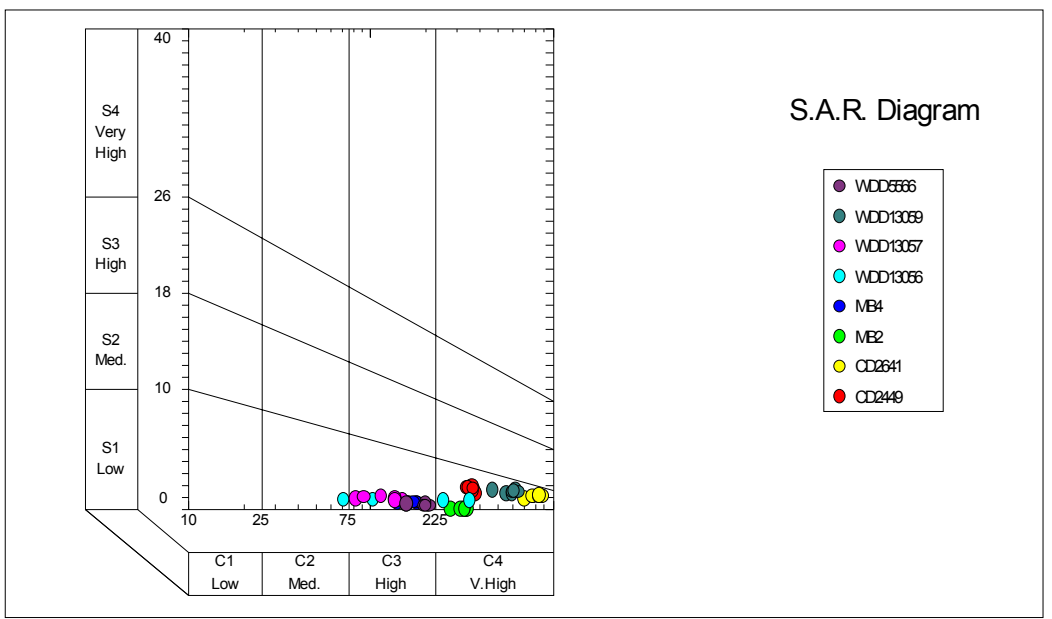

Figure 4: Hydrograph of sodium adsorption ratio to conductivity in $\mu \mathrm{S} / \mathrm{cm}$.

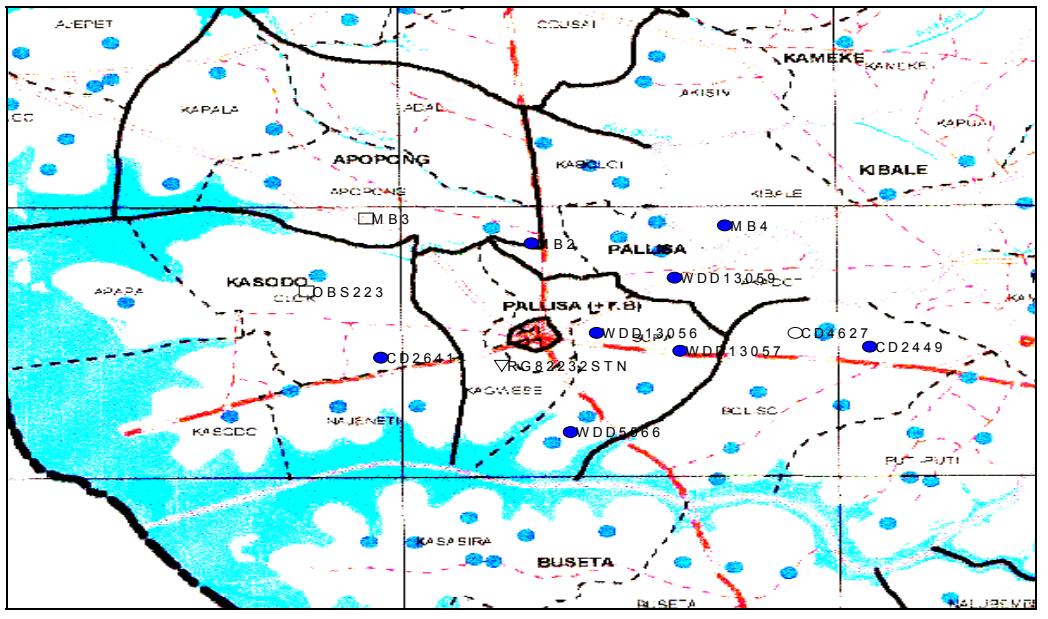

Figure 5: Positions of some of the drilled boreholes around Pallisa town. Source: RUWASA. Scale: 1: 400000.

\section{Discussion of the results}

Figures 2, 3 and 4 shows piper, hydrograph and durov plots of boreholes situated in both the regolith and the basement complex (bed rock) of Pallisa district. 
Looking at the figures 1 and 2, it can be observed that the boreholes situated in these aquifers of Pallisa represent a regime where there is calcium enrichment, which is typical of lime dosing to neutralize acid waters. In the piper diagram, plot of water contains approximately $70 \% \mathrm{Ca}, 70 \% \mathrm{Mg}, 80 \%$ TAlk, $10 \% \mathrm{Cl}$ and $10 \% \mathrm{SO}_{4}$. This is typical of calcium/magnesium bicarbonate waters. So both the regolith and bedrock groundwaters are dominated by the carbonate ions. All in all the groundwaters in Pallisa district are unpolluted and therefore generally suitable for drinking except for few areas with high concentration of iron. Although water rock interactions in both aquifer units may lead to parallel geochemical evolution of groundwater, the data at least do not deny a hydraulic connection. It is known with the exception to correlation is aluminium. Higher concentrations of aluminium are observed in the regolith while low levels in the bedrock. The higher levels of aluminium are the product of highly active weathering in the regolith, in that the bedrock aquifers receives recharge primarily in areas where the aquifer units are sufficiently linked to allow the water to move through the regolith and into the bedrock with minimal geochemical interaction. Where hydraulic interaction is poorly developed, the groundwater will tend to remain in the regolith and the geo-chemical weathering is able to proceed without inhibition.

The significantly lower level of aluminium in the bedrock aquifer provide further support for the notion of relatively limited hydraulic interaction between the two units.

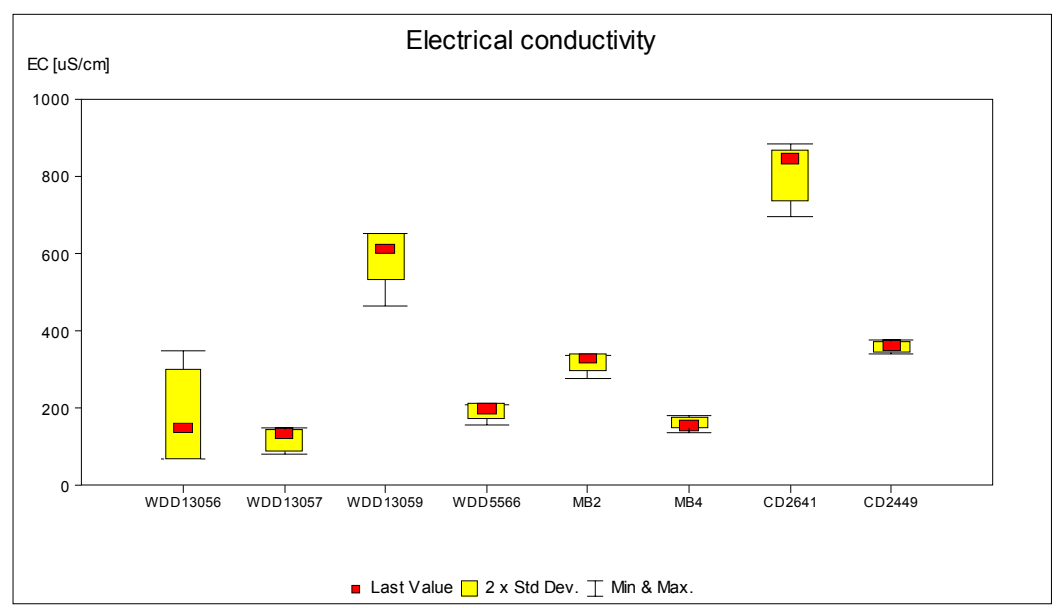

Figure 6: Box and whisker plot of electrical conductivity of the boreholes drilled to less than $800 \mu \mathrm{S} / \mathrm{cm}$. within the basement complex. 


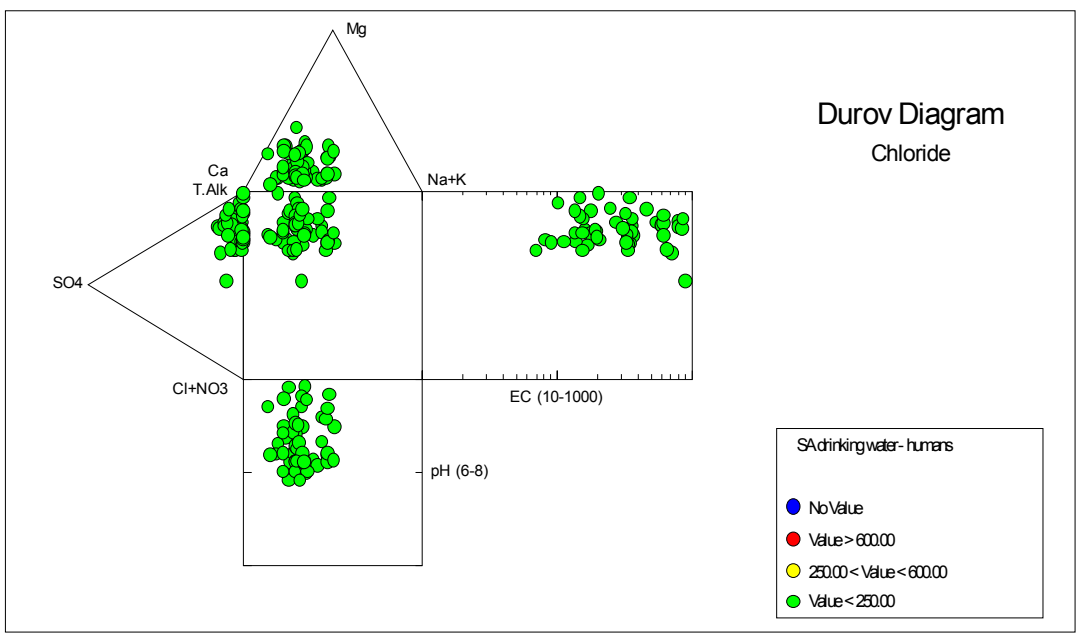

Figure 7: Concentrations of chloride of all the boreholes tested in Pallisa.

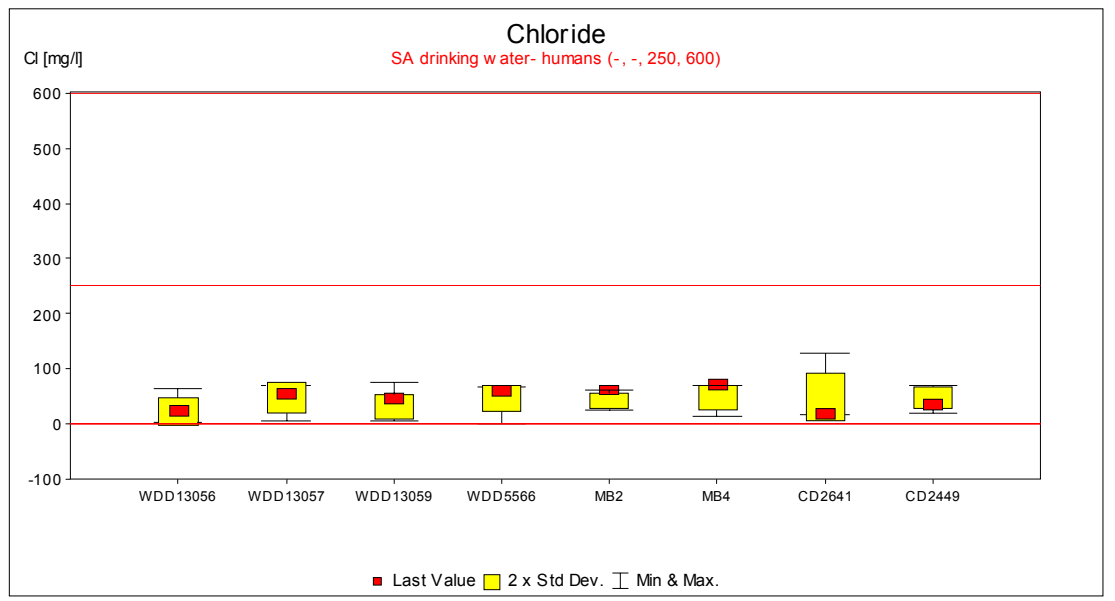

Figure 8: $\quad$ Box and whisker plot of chloride concentration $(\mathrm{mg} / \mathrm{l})$ of boreholes drilled in Pallisa basement complex.

\section{Conclusion}

From a human health point of view, most of the groundwaters are generally acceptable in terms of their inorganic water quality. Aesthetically, however, many groundwaters show excessive levels of aluminium, chloride, iron, manganese, zinc and hardness in a limited number of wells, thus substantiating concerns raised by the consumers nearby some of these wells.

Where health standards are exceeded, nitrate and chromium are the usual problems. Evidence of groundwater quality deterioration is associated with the 
corrosion of the borehole casings and the raising mains, or the seepage of the wastewater into shallow wells from domestic wastes due to insufficient sanitary practices by humans and livestock. Wastewaters are generally responsible for elevated concentrations of chlorides and nitrates, while corroded pipe work increases the contents of iron, zinc and manganese. However, elevated aluminium, iron, manganese and to some extent chromium, are also associated with natural weathering of the aquifer matrix.

Ongoing work as part of the principal author's research aims to finalise the chemical composition of groundwater in Pallisa and a further study in the sodium absorption ratio (SAR) of the soil to be re-evaluated. Given the enormous variations in conductivity over short distances, there is need to study the hydrogeology of the area at a high resolution. This will enable the study and understanding of the spatial variation of hydrogeology and its causes.

\section{Acknowledgements}

The research discussed in this paper emanates from a project funded by Kyambogo University entitled "Evaluation of groundwater resource potential of Pallisa district in eastern Uganda". The financing of this research project by the University is greatly acknowledged.

The author would like to thank Professor F.D.I Hodgson particularly for his contribution in this research, Eng. J.C Kasiita, and Edison Niwagaba for the tremendous work provided. I thank the Departments and the personnel of the DWD Library and WRMD Library, Entebbe, RUWASA and Kyambogo University Library for their assistance and guidance.

\section{References}

[1] Morgan, N.E., Groundwater chemistry and quality assessment of Lake Naivasha area, Kenya. M.Sc. Thesis, International Institute for Aerospace Survey and Earth Sciences, Enschede (ITC).1998. pp.16.

[2] National Curriculum Development Center, Uganda: Geological, soils and natural vegetation maps of Uganda. Scale 1:7 000000 .2001.pp 17.

[3] Key, R.M., An introduction to crystalline basement of Africa. In: Wright, E.P and Burgess W.G (eds), Hydrogeology of crystalline basement aquifers in Africa geological society, London, Publication No. 66. 1992, pp.29-57.

[4] Briggs, D., P. Smithson and T. Ball, Fundamentals of Physical Geography (Can. Ed.) Copp Clerk, Ontario, Canada. 1989. pp.594

[5] Taylor, R.G., K.W.F. Howard, J. Karundu and T. Callist, Distribution and seasonability of groundwater recharge to the regolith basement aquifer system in Uganda. GSA abstracts vol.25, No. 6 (September 1993).

[6] Nyende J. and Hodgson F.D.I, Evaluation of groundwater resource potential of Pallisa district in Eastern Uganda. Institute for groundwater studies, University of the Free State RSA. 2003. pp.11

[7] World Health Organization, Guidelines for Drinking-water Quality, Vol. 1, Recommendations. World 